Vesna Močnik,

Zavod RS za

zaposlovanje Grosuplie

\title{
SKUPNOSTNO IZOBRAŽEVANJE KOT NOVA OBLIKA IZOBRAŽEVANJA ODRASLIH NA PODEŽELJU
}

\section{POVZETEK}

Avtorica predstavi skupnostno izobraževanje in njegove prednosti kot alternativo oblikam izobraževanja odraslih, ki so bile po pregledu ponudbe izobraževanja odraslih v letu 2007/08 (Brenk, 2007) na voljo na trgu. Nadalje na podlagi raziskave prikaže stanje izobraževanja odraslih v podeželski skupnosti. Ves čas zagovarja tezo, da je podeželje postalo prostor, v katerem ima skupnostno izobraževanje velike možnosti postati dejavnik pozitivnih družbenih sprememb. Skupnostno izobraževanje je v prispevku opredeljeno kot oblika izobraževanja, locirana v skupnosti, ki lahko veliko pripomore $k$ ohranjanju obstoječih in graditvi novih socialnih omrežij, aktivaciji krajanov za sodelovanje $v$ skupnosti in $k$ trajnostnemu razvoju podeželskih skupnosti.

Ključne besede: skupnost, podeželje, trajnostni razvoj, socialni kapital, izobraževanje odraslih, skupnostno izobraževanje

Z

globalizacijo nastaja vse bolj poenotena svetovna kultura. Razvojne perspektive Slovenije, Evrope in drugih delov sveta težijo k skladnemu trajnemu razvoju vseh regij. Zaradi nezmožnosti dohitevanja globalizacijskih zapovedi pa nekatere regije zaostajajo, predvsem na socialnem in kulturnem področju. $\mathrm{Na}$ območjih, ki skušajo slediti globalizacijskim zapovedim, je nov razvoj namenjen temu, da privablja nove, predvsem bogate prebivalce. Območja se naseljujejo z ljudmi iz urbanih središč, ki živijo na podeželju in ne občutijo temeljne povezanosti z interesi tega okolja. Podeželske skupnosti, ki so izkusile rast prebivalstva, so hkrati občutile tudi veliko segregacijo populacije. Obstoječe skupnosti oziroma prebivalci in njihove potrebe so spregledani. Ob tem pa želje na podeželju postajajo nostal- gične, osebne in družbene potrebe so vse manj zadovoljene. $\mathrm{V}$ prispevku ugotavljamo, kako so zapostavljene izobraževalne in socialne potrebe krajanov na podeželju ter kakšna je možnost, da skupnostno izobraževanje pripomore $\mathrm{k}$ trajnostnemu razvoju podeželja, predvsem $\mathrm{k}$ njegovi socialni komponenti.

Trajnostni razvoj zahteva nov način življenja in mišljenja, v katerega se morajo vključiti vsi člani nacionalne skupnosti. V globalnem sistemu pa načrtovanje in kasnejše izvajanje največkrat potekata centralno. Zaradi centraliziranega delovanja svetovnega sistema mnogo ljudi pasivno čaka odločitve »od zgoraj《 in pri tem zanemari svojo aktivnost pri izboljševanju pogojev življenja. V tem procesu »čakanja« sprememb »od zgoraj « ostajajo mnoge potrebe ljudi nezadovoljene, kajti nobena sprememba ne ustreza 
potrebam vseh ljudi. Odgovornost za izboljševanje pogojev življenja pa je predvsem v rokah vodilnih teles. Družba bi zato morala sprejeti dejstvo, da lahko sama pripomore k svojemu razvoju in s tem prevzame delno odgovornost za napredek in življenje v skupnosti. Družbo bi bilo treba aktivirati in spremeniti miselnost, da bo za vse spremembe poskrbljeno »top down«, ter usmeriti posameznika k spraševanju o tem, kaj lahko sam stori za svoj boljši jutri ter s tem za razvoj in napredek skupnosti, v kateri živi. Pri tem pa je izobraževanje kot družbena dejavnost in dejavnost posameznika ključnega pomena za razvoj in je vedno povezano z napredkom (Jelenc S., 1996).

\section{IZOBRAŽEVANJE ODRASLIH V SLOVENIJI}

Državni zbor Republike Slovenije je na podlagi 22. člena Zakona o izobraževanju odraslih (Uradni list RS, št. 12/96) ter v povezavi s 107. in 109. členom ter tretjim odstavkom 171. člena Poslovnika državnega zbora (Uradni list RS, št. 35/02 in 60/04) na seji dne 16 . junija 2004 sprejel Resolucijo o nacionalnem programu izobraževanja odraslih $\mathrm{v}$ Republiki Sloveniji do leta 2010, v kateri so bili zajeti tudi podatki različnih raziskav s področja izobraževanja odraslih (ReNPIO 2004). Po treh letih se podatki niso močno spremenili.

V Pregledu ponudbe izobraževanja in učenja odraslih v Sloveniji v šolskem letu 2007/2008 (Brenk, 2007) so ugotovili, da se na trgu, kjer se srečujeta ponudba (izvajalci izobraževalnih programov za odrasle) in povpraševanje (učeči se odrasli), pojavljajo naslednji programi: za osnovnošolsko izobraževanje, za pridobitev izobrazbe po osnovni šoli, vključno z višjimi strokovnimi programi (pridobitev magisterija, doktorata in specializacije), programi usposabljanja za delo po verificiranih in neverificiranih programih, programi vpeljevanja $\mathrm{v}$ delo in pripravništva, programi za usposabljanje in izpopolnjevanje po zakonskih predpisih, za inoviranje temeljnega poklicnega in strokovnega znanja po stopnji zahtevnosti, za razvoj in zagotovitev kakovosti, za vodenje in poslovodenje, za delo $\mathrm{z}$ ljudmi, za informatiko in

V Sloveniji manj-
kajo programi za
spodbujanje in
usposabljanje za
nadaljnje izobra-
ževanje.
računalništvo, za tuje jezike, za sindikalno delo, programi dousposabljanja oziroma dokvalifikacije in preusposabljanja oziroma prekvalifikacije. $\mathrm{V}$ večini so programi za pridobivanje višje stopnje izobrazbe in programi, ki so namenjeni poklicu in poklicnemu delu. Niti ponudba javnoveljavnih programov niti ponudba neformalnih izobraževalnih programov za odrasle v Sloveniji še ni dovolj razvita, saj po mnenju avtorjev ReNPIO (2004) manjkajo predvsem programi za spodbujanje, motiviranje in usposabljanje za nadaljnje izobraževanje ter programi za povezovanje temeljnega izobraževanja s kulturnimi, socialnimi ali ekonomskimi aktivnostmi odraslih in drugi.

Čeprav rezultati, zbrani v Pregledu (Brenk, 2007), kažejo, da je 70,3 odstotka celotne ponudbe izobraževanja odraslih namenjene
Ponudba splošnega neformalnega izobraževanja se v Sloveniji povečuje že od leta 1999. Tako se je to izobraževanje razširilo za skoraj 2.000 programov, kjer najbolj izstopata jezikovno in računalniško področje, ki skupaj pomenita kar polovico celotne izobraževalne ponudbe v Pregledu (Brenk, 2007) in se navadno izvajata na šolah. V vseh slovenskih regijah je največja ponudba jezikovnega izobraževanja, sledi računalniško izobraževanje ter nato različno poklicno in strokovno usposabljanje. Nekaj več kot štiri odstotke je programov s področja vzgoje in izobraževanja, 3,9 odstotka s področja umetnosti in kulture, 3,5 odstotka s področja komunikacije, sledijo ročna dela in programi osebnostne rasti (Brenk, 2007). 
splošnemu neformalnemu izobraževanju, je avtorica poudarila, da se splošno neformalno izobraževanje v praksi pogosto tesno prepleta s poklicnim usposabljanjem in izpopolnjevanjem za potrebe dela.

Jelenc (1990) je izobraževanje odraslih na šolah in univerzah označil kot izrazito tradicionalno, in sicer tako po vsebini programov in programski zasnovanosti kot po načinih in metodah izvedbe ter organiziranosti. Zapisal je (Jelenc, 1990: 25), da so programi po svoji sestavi in vsebini »izvedeni iz programov za otroke in mladino in so le s 'kozmetičnimi' popravki prilagojeni odraslim«. Prevladuje verbalno podajanje znanja s strani predavateljev, pri čemer so aktivnejše metode izobraževanja in učenja zelo redke. Potrebo po večjem vlaganju v razvoj izobraževanja odraslih so podkrepili tudi rezultati mednarodne raziskave o pismenosti odraslih (IALS, 1998-2000), v kateri so sodelovali odrasli od 16. do 65. leta iz 20 držav. Po teh rezultatih slovenski odrasli glede funkcionalne pismenosti sodijo $\mathrm{v}$ petino najslabše pismenih držav. V Sloveniji je namreč kar 77 odstotkov odraslega prebivalstva po svojih dosežkih pod ravnjo, ki je potrebna za razumevanje in uporabo tiskanih (pisnih) informacij v vsakdanjem življenju (Nacionalna strategija za razvoj pismenosti 2006). Potrebo po novih prijemih v izobraževanju odraslih potrjujejo tudi raziskovalni izsledki, pridobljeni v raziskavi Andragoškega centra Slovenije $\gg$ Razvoj izobraževalnega modela za zviševanje ravni pismenosti in trajnostni razvoj podeželja « (CRP 2001-2006), ki so pokazali, da le 10 odstotkov odraslih na podeželju dosega raven pismenosti, ki ustreza zahtevam današnjega časa, nekaj manj kot polovica (42 odstotkov) odraslih na podeželju pa ima dokončano le osnovno šolo ali manj (Izzivi podeželja 2005).

Večina ukrepov in spodbud za razvoj izobraževanja odraslih prihaja $\mathrm{z}$ državne ravni. S spremenjenimi potrebami po izobraževanju, ki jih prinašajo globalizacija in spremenje- ni stili življenja, se bo morala okrepiti vloga lokalnih skupnosti oziroma občin in regij. V ReNPIO (2004) namreč ugotavljajo, da lokalne in regionalne skupnosti še vedno ne prevzemajo pomembnejše vloge pri povezovanju izvajalskih institucij, razvijanju, financiranju in spodbujanju izobraževanja v svojih okoljih, zlasti za splošno izobraževanje prebivalcev, izobraževanje za demokracijo in večjo socialno vključenost. Tudi izobraževalne organizacije bodo morale bolj kot doslej prisluhniti izobraževalnim potrebam ljudi in skupnosti. Opisane razmere na področju izobraževanja odraslih kličejo po novih oblikah izobraževanja in drugačnih prijemih. Krajnc (1996: 23) ugotavlja, da se ljudje »čedalje bolj zavedajo, da je treba izobraževanje odraslih čimbolj povezati z življenjem, s potrebami ljudi in kraja, kjer živijo«. Vendar pa po ugotovitvah Findeisenove (1996) v Sloveniji še nimamo take oblike izobraževanja, ki bi lahko povečala možnosti za izobraževanje na podeželju in socialno vključevanje prebivalstva, pripomogla k enakomernejšemu razvoju regij ter prebudila lokalno iniciativo. Drugod po Evropi je bila demokratizacija in s tem prebujanje lokalne iniciative ter neposrednega odločanja ljudi $\mathrm{v}$ zadnjih 20 letih povezana prav $\mathrm{z}$ razvojem skupnostnega izobraževanja in splošno demokratizacijo družb.

\section{SKUPNOSTNO IZOBRAŽEVANJE}

Za večino ljudi od otroštva do starosti učenje poteka v domačem okolju. Pri tem mora lokalna skupnost zagotavljati ustrezne zmogljivosti in možnosti za učenje. Različne lokalno dostopne učne možnosti pomenijo, da ljudem ni treba zapuščati domačega okolja zaradi zadovoljevanja potreb po učenju in druženju $\mathrm{z}$ namenom izboljševanja kakovosti svojega življenja (Jelenc, 2007). Odrasli bi morali torej v skupnosti, kjer prebivajo, imeti na voljo različne programe izobraževanja in usposabljanja, ki bi jih lahko izkoristili za svoj osebni razvoj. S 
Pri ideji skupnostnega izobraževanja gre za aktivno sodelovanje, za približevanje izobraževanja potrebam ljudi v kraju in s tem potrebam celotne skupnosti (npr. ohranjanje kulturne dediščine, skrb za osamljene starejše ljudi ali ureditev igrišča za otroke). Na podlagi prepoznanih potreb se ljudje združujejo v posamezne interesne skupine, v katerih postavijo cilje svojega delovanja in učenja (Ličen, 1996). Pri tem ne gre za poučevanje o določenih tematikah, ampak za skupnostno akcijo, ki združuje vrednote in občutek pripadnosti skupnosti. Teorija in praksa skupnostno izobraževanje definirata kot izobraževanje za skupnost in v skupnosti, kar pomeni, da skupnost ni le prostor, kjer poteka izobraževanje, ampak je osrednja skrb izobraževanja vzgojiti in ohraniti skupnost.

tem, ko bi se odrasli vključevali v izobraževalne dejavnosti v svojem okolju, bi pripomogli tudi k izboljševanju stanja v družbi. Možnosti za učenje pa bi morale biti organizirane tako, da zadovoljijo tako potrebe posameznika kot tudi družbene potrebe. To pomeni, da bi morali biti izobraževalni programi in različne izobraževalne dejavnosti prilagojeni potrebam in interesom posameznika, ne le družbenim potrebam, kar bi povečalo motivacijo odraslih za vključevanje v izobraževanje. Koncept skupnostnega izobraževanja izhaja iz skupnostnih potreb in interesov.

AONTAS (Community education, 2000), irsko nacionalno združenje za izobraževanje odraslih, skupnostno izobraževanje opredeljuje kot proces ustvarjanja moči, socialne pravičnosti, sprememb, izzivov, spoštovanja in skupnostnega zavedanja. Ta proces poteka znotraj skupnosti in iz skupnosti, odsevajoč razvijajoče se potrebe posameznikov in njihove soseske. Lokalnim skupnostim gradi zmogljivosti za vključevanje v odzivanje na izobraževalne in strukturne pomanjkljivosti ter za udeležbo $\mathrm{v}$ procesu odločanja in oblikovanja politike znotraj skupnosti. Izobraževanje, ki spodbuja aktivno sodelovanje in potrebo po iskanju rešitev $\mathrm{v}$ sodelovanju in skupaj z drugimi, tako postaja adut za učinkovito uresničevanje ciljev in vsebin trajnostnega razvoja. Na ravni soseske lahko pomembno pripomore k zadovoljevanju potreb ljudi in skupnosti, ki se počutijo najbolj izolirane in nezadovoljne, s čimer lahko poveča možnosti za izobraževanje predvsem $\mathrm{v}$ podeželskih skupnostih. V skupnosti naj bi si zato prizadevali za vzpostavljanje konteksta, v katerem se bodo udeleženci učili komunicirati tako, da bodo usmerjeni $\mathrm{v}$ ohranjanje skupnosti, konstruktivno reševanje problemov in sodelovanje. Pri tem pa se nam postavlja vprašanje, kako lahko v današnjem kapitalističnem svetu, kjer še vedno vladata centralizacija sistema in individualizacija prej kolektivne lastnine, $\mathrm{z}$ izobraževanjem ustvarimo družbeni prostor oziroma takšno podeželsko skupnost, v kateri bodo krajani vključeni v družbeno življe-

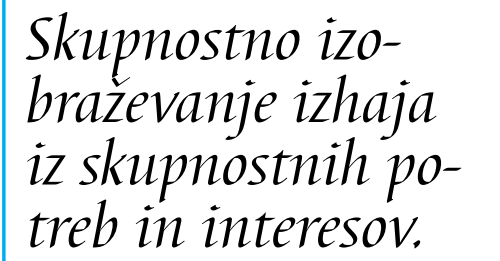
brazevanje izhaja iz skupnostnih potreb in interesov. procesom odločanja o skupnostnih zadevah ter nasploh dejavni državljani.

\section{RAZVOJ IN POJAVNOST IDEJE SKUPNOSTNEGA IZOBRAŽEVANJA}

Sintagma »skupnostno izobraževanje« je v Sloveniji sorazmerno nova, vendar ima bogato ozadje, saj so za dvig kakovosti življenja v skupnosti nekoč skrbela različna društva. Obstajale so čitalnice, hranilnice, zavarovalnice, denimo za pospeševanje razvoja kmetijstva na vasi, kjer so se ljudje skupaj učili. Različni prostori v skupnosti so tako postali izobraževalna središča. Institucije, ki skrbijo za izobraževanje v lokalni skupnosti, so nastale predvsem na pobudo posameznikov, ki so v svojem kraju začutili potrebo prisluhniti ljudem, predvsem njihovim interesom, in jim dati možnosti za pridobivanje novih znanj in razvoj civilizacijskih kompetenc (Ličen, 2001). 
Skupnostno izobraževanje izvira iz Velike Britanije in ZDA. Koncept si je sposodilo mnogo zahodnih držav in tako so se razvile različne oblike skupnostnega izobraževanja (Krüger in Poster, 1990). Ena izmed njih je učenje, ki temelji na skupnosti (Community based learning ali Service learning) in združuje storitvene dejavnosti $\mathrm{z}$ akademskim učenjem ter je močno vezano na specifične učne cilje. Ta model želi zagotoviti, da bo neka aktivnost koristila tako sprejemniku (učencu na šoli) kot tudi izvajalcu oziroma partnerju (članu skupnosti). Community based learning združuje učenje $\mathrm{v}$ razredu $\mathrm{z}$ učenjem $\mathrm{v}$ skupnosti (Holland, Robinson, 2008).

Druga oblika tega izobraževanja je skupnostna šola (community school), opis katere je podal Tony Jeffs (1999 v Smith, 2008): skupnostna šola je »odprta «. To pomeni odprtost dela $\mathrm{V}$ razredu, administrativnem procesu in obliki zgradbe, ki se kaže v tem, da nima ograj, ki bi preprečevale stik s prebivalstvom; taka šola ima javno dostopno infrastrukturo in storitve za lokalno prebivalstvo in druge ter je locirana v središču skupnosti. Hasley (1972 v Smith, 2008) kot cilj tega modela skupnostnega izobraževanja opredeli težnjo po povezovanju šole z lokalno skupnostjo, ki bi usmerila skupnost $\mathrm{k}$ šoli in šolo k skupnosti.

V Angliji in še nekaterih drugih državah pa je skupnostno izobraževanje zaznamovano s pionirskim delom Henryja Morrisa in njegovih »vaških kolidžev« (village college). Morris (1925 v Krüger in Poster, 1990) jih je opisal kot prostor, za katerega je značilna dualnost izobraževanja in vsakdanjega življenja. Vaški kolidži niso le prostor usposabljanja za življenje, ampak prostor, kjer se življenje živi, okolje skupnega življenja. Posameznik vstopi vanj pri treh letih in ga zapusti v zelo pozni starosti. Izobraževanje $\mathrm{v}$ tem smislu pomeni obogatitev življenja skupnosti. Ta model združuje in ponuja različne aktivnosti, prostore oziroma organizacije, kot so: šola, vaška dvorana, bralna soba, večerni tečaji, tečaji kmetijstva, ženski inštitut, skavti, rekreacijski prostor, podežel- ska knjižnica, atletika in klubi za rekreacijo. $\mathrm{S}$ tem ustvarja novo obliko enotnosti in novo skupno institucijo za podeželje. Po mnenju Morrisa (1925 v Krüger in Poster, 1990) bi vaški kolidži spremenili celotno sliko problema izobraževanja na podeželju.

Četrti model je full-service school oziroma »šola, ki vključuje vse storitve« (Dryfoos 1994 v Smith, 2008), in sicer izobraževalne, zdravstvene, socialne in druge osebne storitve, ki prispevajo k zadovoljevanju potreb vseh prebivalcev ter njihovih družin na vsem dostopnem šolskem območju.

V svetu se torej uveljavljajo različne alternativne oblike skupnostnega izobraževanja, ki jih tradicionalna izobraževalna ponudba ni poznala. Programi skupnostnega izobraževanja skušajo ustvariti takšno pripadnost skupnosti, ki bo spodbudila krajane k sodelovanju v razvoju njihovega kraja in oživljanju identitete lokalne skupnosti. Dejavnosti, ki se izvajajo v okviru skupnostnega izobraževanja, so različne. Raziskovalno poročilo Evropskega sveta $\mathrm{z}$ naslovom »Aktivno državljanstvo in skupnostno udejstvovanje, do korenin « je leta 1999 (v Community education, 2000) navedlo naslednje aktivnosti:

- organizacija vzajemne pomoči,

- izvajanje družabnih in rekreativnih aktivnosti,

- različne kampanje na lokalni ravni,

- sodelovanje $\mathrm{z}$ oblastmi $\mathrm{v}$ imenu prebivalcev,

- dajanje informacij, nasvetov ali pomoči na področju različnih družbenih tematik, kot so zdravje, izobraževanje ali zaposlovanje,

- omogočanje komunikacije na lokalni ravni prek izdajanja skupnostnega časopisa ali oddajanja radijske postaje,

- omogočanje sklepanja prijateljstev in preseganja izolacije med ljudmi,

- širitev informacij o lokalnem razvoju in možnostih ter

- omogočanje razvoja novih spretnosti s prevzemanjem nalog za skupnost. 
Ključne značilnosti skupnostnega izobraževanja so (Community education, 2000):

- skupnostno izobraževanje je umeščeno v skupnost;

- vključuje učne programe, ki so oblikovani na podlagi identificiranih potreb skupnosti;

- nadzor ostaja v rokah lokalne skupnosti;

- učne tehnike in tehnike poučevanja temeljijo na svobodi in človeških vrednotah;

- skupnostno izobraževanje z razvojem človeških potencialov omogoča osebnostno rast in razvoj ljudi;

- izkušnje udeležencev so podlaga za učenje;

- njegovi učinki so dvosmerni in medsebojno povezani:

- osebno pridobivanje spretnosti, znanja in nadaljnjih usmeritev,

- socialno in skupnostno pridobivanje moči ter napredovanje.

Aktivnosti skupnostnega izobraževanja v svojem jedru vključujejo učenje, v ospredje pa postavljajo potrebo po izvedbi, v kateri so aktivnosti zasnovane za skupnost in oblikovane za nenehno odzivanje na aktualne probleme (Zacharakis, 2008).

Cilj mnogih tečajev ali programov skupnostnega izobraževanja je omogočiti ljudem analiziranje in izzivanje svoje lastne pozicije v družbi (Community education, 2000). Raznovrstnost v izvajanju teh aktivnosti spodbuja prehod od posameznikovih potreb k razvoju spretnosti za aktivno vključevanje v skupnost, na trg delovne sile in $\mathrm{v}$ družbo. Učni proces osebnostno bogati posameznike, jih motivira za nadaljnje vključevanje v izobraževanje, kar pa ne vodi nujno v vstopanje na trg delovne sile. Učenje $\mathrm{v}$ skupnostnem izobraževanju je mišljeno kot odskočna deska za druge oblike učenja, programi pa so zasnovani tako, da upoštevajo stopnjo razvoja udeleženca in način njegovega vrednotenja lastnih izkušenj. Pri tem je poudarek na povečevanju samozavedanja in samozavesti kot mehanizmu za posameznikov napredek. V Sloveniji so primeri oblik izobraževanja v skupnosti medgeneracijski programi, ki dopolnjujejo različne oblike skupnostnega izobraževanja in prostovoljnega dela (Kump, Jelenc Krašovec, 2005). Način, kako organizirati skupnostno izobraževanje, da bo lahko kar najbolj uresničevalo svoje cilje, pa še vedno ostaja problem.

\section{PROBLEM RAZISKOVANJA}

Na podlagi teh spoznanj smo izvedli empirično raziskavo stanja na podeželju $\mathrm{z}$ vidika skupnostnega izobraževanja. V prispevku predstavljamo del raziskave, ki se je nanašal na ugotavljanje izobraževalnih in socialnih potreb krajanov podeželske skupnosti ter ugotavljanje možnosti za vpeljavo nove oblike izobraževanja odraslih v podeželske skupnosti.

\section{OPIS VZORCA}

V raziskavo smo zajeli 1,6 odstotka vseh članov izbrane lokalne skupnosti oziroma 102 osebi od 6.358 prebivalcev. Glede na spolno sestavo prebivalstva $v$ občini smo $v$ raziskavo zajeli 1,4 odstotka vseh moških (3.097) in 1,8 odstotka vseh žensk (3.261). Vzorec, zajet v prvem delu raziskave, ki smo jo opravili s pomočjo anketnega vprašalnika, je bil izbran priložnostno. Vanj sta bili vključeni 102 priložnostno izbrani osebi, od tega 60 ( 58,8 odstotka) žensk in 42 ( 41,2 odstotka) moških. Anketirali smo prebivalce v sedmih krajih v gorenjski regiji, ki sodijo v izbrano večjo podeželsko občino. Situacija, ki smo jo raziskovali, je večplastna, zato je nanjo mogoče gledati z več vidikov. Od anketirancev je bilo največ oseb starih od 25 do 40 let, teh je bila skoraj polovica (47,1 odstotka). Sledijo anketiranci, stari od 41 do 65 let, katerih je bilo v vzorcu 40,2 odstotka. Najmanjšo starostno skupino pa $\mathrm{v}$ raziskavi sestavljajo osebe, starejše od 65 let, 
teh je bilo le 13 oziroma 12,7 odstotka. Več kot polovica anketiranih oseb je imela srednješolsko izobrazbo (64,7 odstotka), sledijo jim anketiranci s končano osnovnošolsko izobrazbo, ki jih je bilo 14,7 odstotka. Enajst oseb (10,8 odstotka) je imelo visoko oziroma višješolsko izobrazbo, 7,8 odstotka univerzitetno, le dve osebi izmed 102 anketiranih pa sta imeli magisterij.

$\mathrm{V}$ drugi del raziskave, ki smo jo opravili v obliki intervjujev, so bile vključene tri osebe, izbrane tako, da so v starostni strukturi najbolj zastopale naslednje starostne skupine odraslih, ki si sledijo z linearnega vidika (Schaie, Willis 2001 v Ličen, 2006):

1. obdobje mlajše in zgodnje odraslosti, ki traja od 25. do 40. leta starosti,

2. srednja odrasla doba, ki zajema čas od 40 . do 65. leta starosti,

3. mlajša starostna doba in doba starosti, ki se začne s 65 . in sega prek 75. leta starosti.

Tako smo upoštevali vidike treh starostnih skupin: mlajše odrasle, srednje odrasle in starejše. Obdobje mlajše oziroma zgodnje odraslosti je »zastopala« 29-letna ženska, srednjo odraslo dobo 44-letni moški, mlajšo starostno dobo oziroma dobo starosti pa 67-letni moški. Poznavanje treh različnih starostnih pogledov na situacijo, ki smo jo proučevali, nam omogoča iskanje skupne rešitve za naš raziskovalni problem. Intervjujali smo tri osebe različnih starosti, pri čemer smo se odpovedali ideji reprezentativnega vzorčenja, statističnega posploševanja na širšo populacijo in hipotetično množico ter se pri tem opredelili za analitično indukcijo.

\section{UGOTOVITVE RAZISKAVE}

V izbrani podeželski skupnosti delujejo različna kulturna (umetniška, likovna, pevski zbor), športna, turistična in druga društva, kot so: gasilsko društvo, konjeniško, čebelarsko, društvo obrtnikov in podjetnikov, aktiv kmečkih žena, avto-moto društvo, društvo upokojencev, Moped Tour, krajevna organizacija ZB NOV, sekcija narodnih noš, ribiška družina »Bistrica«, društvo za vzpodbujanje kreativnosti »Igrišče « itd. Aktivna je tudi katoliška dobrodelna organizacija Karitas, v okviru katere deluje mladinski center, pa še dobrodelna organizacija Rdečega križa. Iz podatkov, pridobljenih $\mathrm{z}$ anketiranjem, smo ugotovili, da ponudba ne zadovoljuje interesov vseh starostnih skupin odraslih, saj so dejavnosti namenjene predvsem upokojencem. To je opazila 29-letna intervjuvanka, ki je ocenila, da je v podeželski skupnosti premalo možnosti za druženje, sodelovanje in povezovanje krajanov. Z njeno ugotovitvijo se je strinjala skoraj polovica anketiranih $(45,5$ odstotka), ki je ocenila, da v njihovi podeželski skupnosti obstaja le nekaj izobraževalnih in kulturnih dejavnosti, 35,6 odstotka anketirancev pa je menilo, da je ponudba premalo pestra. Iz dejanske ponudbe podeželske skupnosti, ki smo jo raziskovali, vidimo, da je organizacij kar nekaj. Je pa vprašanje, koliko so te dejavnosti odprte za vse krajane in prožne $\mathrm{v}$ prilagajanju oziroma koliko so namenjene le peščici ljudi, krogu oseb, ki so vanje vključeni že od samega nastanka ali pa so se vključili prek družine oziroma prijateljev.

Pri tem se nam zdi pomembna ovira, ki so jo $\mathrm{v}$ svojih odgovorih navedli intervjuvanci, in sicer slaba seznanjenost $\mathrm{z}$ dogajanjem $\mathrm{v}$ skupnosti. Obveščanje krajanov o dogodkih, dejavnostih in drugih novostih ter možnostih, ki jih ponuja skupnost, je pomanjkljivo. 29-letna intervjuvanka je dejala: »Nismo obveščeni, to se pravi nismo povabljeni ...«44-letnik pa je po-

Tabela 1: Ocena kakovosti izobraževalnih in kulturnih dejavnosti v podeželski skupnosti anketirancev

\begin{tabular}{|l|c|c|c|c|c|}
\hline Ocena kakovosti ponudbe & $\begin{array}{l}\text { Zelo dobra, saj } \\
\text { smo njihovih koristi } \\
\text { deležni vsi krajani }\end{array}$ & $\begin{array}{l}\text { Dobra, tudi krajani so } \\
\text { seznanjeni z njihovim } \\
\text { delovanjem }\end{array}$ & $\begin{array}{l}\text { Slaba, dejavnosti } \\
\text { so namenjene le } \\
\text { peščici ljudi }\end{array}$ & $\begin{array}{l}\text { Ne morem oceniti, ker } \\
\text { ne poznam njihovega } \\
\text { delovanja }\end{array}$ & $\begin{array}{l}\text { Drugo } \\
\text { Skupai }\end{array}$ \\
\hline vodstotkih & 2,0 & 37,3 & 28,4 & 26,5 & 5,9 \\
\hline
\end{tabular}


Jelenc (1990) je zapisal, da je ponudba neformalnega izobraževanja v različnih organizacijah, društvih in klubih le navidezno bogata, saj je dostop omejen le na ožji krog morebitnih udeležencev, kot so člani organizacij ali zaposleni v isti ali sorodni organizaciji. To je potrdilo tudi 28,4 odstotka anketirancev, ki so pri ocenjevanju kakovosti obstoječih izobraževalnih in kulturnih dejavnosti odgovorili, da je kakovost $\mathrm{z}$ vidika dostopnosti slaba, ker so dejavnosti namenjene le peščici ljudi, 26,5 odstotka anketirancev pa delovanja obstoječih organizacij sploh ne pozna.

vedal: »Mislim, da manjka predvsem informacij o dogodkih ... Za vsak tisi Hofer, Merkur dobimo na dom v nabiralnikih, kar se pa doma dogaja, pa redko. Redko, ne bom rekel nikoli, redko.« Informiranje v tej podeželski skupnosti pogosto poteka »od ust do ust«, kar je ovira, če so odnosi med sosedi skrhani in je komunikacija med krajani slaba. Več kot polovica anketirancev (51,0 odstotka) je namreč potrdila, da se s sosedi pozdravijo in pogovarjajo le, kadar se srečajo. Iz tega lahko sklepamo, da so medosebni odnosi med krajani dokaj skrhani, saj je že komunikacija med sosedi slaba, vezi med njimi so torej šibke, kar pomeni tudi moteno pot komunikacije in informiranja o dejavnostih in dogodkih. Nizka stopnja interakcije med sosedi zmanjšuje tudi socialni kapital v podeželski skupnosti.

\section{NEZADOVOLJENE POTREBE - NERAZVITOST LOKALNE DEMOKRACIJE ALI PASIVNOST KRAJANOV}

Najmanj so v skupnosti zadovoljene potrebe po druženju in sodelovanju. Pri tem naj opozorimo, da krajani menijo, da ima za njihove interese in potrebe premalo posluha lokalna oblast.

Iz tega lahko sklepamo, da je lokalna oblast premalo odprta za predloge krajanov ali pa so možnosti za sodelovanje pri sprejemanju odločitev o zadevah lokalne skupnosti, ki se nanašajo na socialno življenje, omejene. Sprašujemo se, ali gre dejansko za premajhno podporo lokalne oblasti ali zgolj za pasivnost članov podeželske skupnosti. Iz večine odgovorov intervjuvancev je razvidna pasivnost krajanov, ki se kaže kot čakanje na spremembe, naslanjanje na vodilna telesa lokalne oblasti, ki po njihovem mnenju premalo naredijo za krajane. Ali je problem povezan z nerazvitostjo lokalne demokracije? Tako je pojasnil 67-letni intervjuvanec: »V̌̌asih so bili občni zbori. Na te je lahko prišel vsakdo, pa so tam predelali vse vaške stvari, finance, kaj bodo naredili, kaj so naredili prejšnje leto, kaj imajo namen narediti. Kot politika tam $v$ parlamentu ... niso samo tisti svetniki bili notri. Zato so bile manjše vasi tukaj v prednosti.« Intervjuvanec nakazuje na pomanjkanje možnosti za sodelovanje krajanov v procesu odločanja, kar pomeni premalo razvito lokalno demokracijo. To se kaže v tem, da imajo krajani le možnost posrednega odločanja, neposredne oblike odločanja, kot so zbori občanov ali referendumi in odločanje prek ljudske iniciative, ki so uradno določene možnosti v Zakonu o lokalni samoupravi iz leta 1993 (44. člen), pa so v podeželski skupnosti intervjuvanca premalo razvite. Kje tičijo vzroki, da te možnosti ne zaživijo? V slabi informiranosti o možnostih, ki jih imajo za uresničevanje svojih interesov, ali ponovno $\mathrm{v}$ pasivnosti posameznikov? Dejstvo je, da oblike participacije, ki jih omogoča zakonodaja, v praksi ne zaživijo v zadostni meri, čeprav gre razvoj lokalne samouprave v smeri približevanja oblasti ljudem. Če o neki stvari odloča oblast na državni ravni, je to dlje od konkretnih problemov ljudi, kot če o tem odloča lokalna skupnost. Pa vendar se kljub možnostim še vedno 
srečujemo s pasivnostjo ljudi in se sprašujemo, kako jo premagati. Za spodbujanje aktivnosti članov podeželskih skupnosti bi poleg razvitosti oblik neposrednega odločanja potrebovali tudi razvoj ustrezne ponudbe izobraževalnih in skupnostnih dejavnosti. Titmus (1989c v Jelenc, 2007/b) je prepričan, da vsak odrasli potrebuje ustrezne možnosti za izobraževanje in da ni dovolj le zapis na papirju, da je izobraževanje njegova temeljna pravica, saj je to, da se vsak posameznik izobražuje tudi v odrasli dobi, družbi potrebno.

\section{VKLJUČITEV KRAJANOV V IZOBRAŽEVALNE IN SKUPNOSTNE AKTIVNOSTI}

Za krajane ima opisano stanje določene posledice, saj se 90,1 odstotka anketirancev ne vključuje $\mathrm{v}$ izobraževalne in kulturne dejavnosti v svoji podeželski skupnosti, 72,7 odstotka pa jih ne sodeluje niti v skupnostnih aktivnostih. Med razlogi za nesodelovanje v skupnostnih aktivnostih so navajali predvsem situacijske ovire (pomanjkanje časa), nekatere institucionalne (neobveščenost o možnostih sodelovanja), 43,7 odstotka pa jih je menilo, da nimajo dovolj možnosti za sodelovanje, da so projekti neustrezni oziroma jih ne pritegnejo k sodelovanju. Podatki o sodelovanju članov podeželskih skupnosti v skupnostnih aktivnostih (27,3 odstotka) in njihovem vključevanju v izobraževalne in kulturne dejavnosti (9,9 odstotka) nakazujejo, da lokalna skupnost prevzema premajhno vlogo pri povezovanju ljudi za razvoj skupnosti in pri spodbujanju izobraževanja v svojih okoljih.

Tretjina anketirancev (34,0 odstotka) je izrazila željo po večjem vključevanju v izobraževalne in kulturne dejavnosti, željo po večjem sodelovanju v skupnostnih aktivnostih pa 44,4 odstotka anketiranih. Pri tem smo ugotovili, da se želja po vključevanju v izobraževalne in kulturne dejavnosti in želja po sodelovanju v skupnostnih aktivnostih ter po vključitvi v skupnostno izo- braževanje s staranjem zmanjšujeta. Na podlagi deleža anketirancev, vključenih v skupnostne dejavnosti (27,3 odstotka), ki je večji kot delež vključenih v izobraževalne in kulturne dejavnosti (9,9 odstotka), ter navedenih razlogov smo sklepali, da krajani na podeželju raje sodelujejo in bi radi sodelovali v skupnostnih aktivnostih, vendar jim njihova podeželska skupnost - po mnenju intervjuvancev - ne nudi dovolj možnosti za sodelovanje. Mnenje intervjuvanjcev je podprla več kot polovica anketirancev $(56,3$ odstotka), medtem ko je bilo 43,8 odstotka anketirancev z možnostmi sodelovanja v skupnostnih aktivnostih zadovoljnih. Pri tem smo dokazali, da starost vpliva na mnenje o zadostnih možnostih za sodelovanje v skupnostnih aktivnostih. Starejši kot so, bolj so prepričani, da je v skupnosti dovolj možnosti za sodelovanje v skupnostnih aktivnostih. To lahko pojasnimo z eno od dokazanih hipotez, da se $\mathrm{z}$ večjo starostjo želja po sodelovanju v skupnostnih dejavnostih zmanjšuje, zato so možnosti, čeprav so te $\mathrm{v}$ podeželski skupnosti lahko majhne, za starejšo populacijo odraslih krajanov zadovoljive prej kot za mlajšo.

Motivacija za učenje in izobraževanje se s starostjo zmanjšuje in je odvisna zlasti od ustreznih spodbud v okolju (Dwyer idr. 2000 v Kump, Jelenc Krašovec, 2005), pa tudi od stališč krajanov do učenja in izobraževanja. Stališče krajanov do izobraževanja kot potencialnega dejavnika za izboljšanje življenja v njihovi podeželski skupnosti z vidika povezovanja ljudi v skupnost, medsebojnega druženja, vzajemne pomoči in sodelovanja je bilo v večini pozitivno. Presenetljivo je bilo 84,3 odstotka anketirancev mnenja, da bi izobraževanje lahko izboljšalo kakovost socialnega življenja v njihovi podeželski skupnosti. Svoj odgovor so morali tudi pojasniti. Anketiranci so največkrat (17,7 odstotka) predlagali izvedbo različnih oblik izobraževanj v podeželski skupnosti. Navajali so gospodinjske in plesne tečaje, tečaje ročnih spretnosti, jezikovne tečaje, seminarje, predavanja in delavnice o različnih temah, denimo o kmetijstvu in 
ekologiji, vzgoji otrok, zdravju in drugo. 16,7 odstotka jih je za izboljševanje kakovosti socialnega življenja predlagalo vključevanje krajanov $\mathrm{v}$ društva, izobraževalne centre in druge organizacije, 12,8 odstotka krajanov pa je predlagalo medgeneracijsko izobraževanje, različne kulturne dejavnosti, razstave, skupne pohode in drugo. Krajani večinoma menijo, da bi kakovost socialnega življenja na podeželju najbolj izboljšale različne izobraževalne dejavnosti, ki jih v njihovi podeželski skupnosti zelo primanjkuje.

V splošnem interesu demokratične družbe je vsakemu posamezniku zagotoviti možnost za izobraževanje, da lahko postane aktiven državljan in sodeluje $\mathrm{v}$ skupnosti. To pa zahteva javno odgovornost za izvajanje izobraževanja, ki se odziva na zaznane interese in potrebe ter je odprto za vse ljudi ne glede na njihovo izobrazbo, prihodke, status, poklic, državljanstvo ter versko in politično pripadnost. Cilj takšnega integrativnega sistema lokalnega izobraževanja ni uniformiranost idej, ampak odprtost bogate ponudbe življenjskih vzorcev, mentalitet, kulturnih identitet in osebnih perspektiv. Pri tem je treba opozoriti, da odgovornost podeželske skupnosti za izobraževanje ne bi smela biti izpostavljena odprtemu trgu. Dosedanje izkušnje namreč kažejo, da prosti trg pri izobraževanju spodbuja težnjo ponudnikov, da se osredotočajo na povpraševalce $z$ dobro osnovno izobrazbo na dobro preskrbljenih območjih. Primerjalno privilegirana ciljna skupina zagotavlja visoko stopnjo pedagoškega in finančnega uspeha $\mathrm{z}$ relativno majhnim vložkom. Prosti trg za izobraževanje s svojo naravo pospešuje tudi tekmovalnost in segregacijo namesto solidarnosti in integracije znotraj skupnosti (Grant in Horrocks, 2004). Podeželske skupnosti potrebujejo izobraževalne in skupnostne dejavnosti, ki so povezane v konceptu skupnostnega izobraževanja oziroma v sistemu znotraj skupnosti, ki ga izvaja široka mreža institucij, vključno s šolami, agencijami za usposabljanje, univerzami, cerkvami in drugimi, ki lokalni skupnosti omogočajo dostop do svojih zmogljivosti in storitev (zelena knjiga iz leta 1998 v Community education, 2000).

Za organizacijo mreže navedenih institucij bi bilo najprej treba zagotoviti njihovo pripravljenost za medsebojno sodelovanje. Največ truda bi morali po mnenju intervjuvanca vložiti v vzpostavitev sodelovanja med cerkvijo in ostalimi organizacijami. Ponudba izobraževalnih, kulturnih in skupnostnih aktivnosti je na podeželju dobro razvita predvsem v verskih organizacijah, nereligiozne organizacije oziroma njihove dejavnosti pa so prepuščene podpori lokalne oblasti, ki je dobivajo premalo. Prepad med ateisti in verniki v podeželskih skupnostih, ki je nastal kot posledica delitve ljudi v preteklosti na komuniste in vernike, je še vedno velik. Interesi so na podeželju razdrobljeni in nimajo povezovalnega člena. Tako je dejal 44-letni intervjuvanec: »To je tukaj, pri nas, na vasi. Nekdo, ki bo zmagal ta dva pola vsaj približat skupaj, ta bo zmagovalec! Ta dva bregova sta na podeželju še toliko narzen, da bi res rabil engea fenomenalca, ki je neobremenjen, ali pa ki je tako dobro obveščen z obeh strani, ali pa solidno sprejet $z$ obeh strani, da to združi. «

$\mathrm{Bi}$ ta fenomenalec lahko bilo skupnostno izobraževanje? Krajane bi združevalo v skupnostnih aktivnostih, ki bi bile osvobojene verskih ideologij. Namen skupnostnih aktivnosti bi bil izboljševanje kakovosti življenja v skupnosti, ki je bivališče in dom vseh krajanov ne glede na njihovo raso, politično ali versko pripadnost. Vendar vemo, da ima vsaka skupnost svojo zgodbo in zgodovino. Pretekle izkušnje, dominantni verski in politični okviri ter družbene vloge, ki pogosto definirajo in oblikujejo pričakovanja članov skupnosti, so imperativ izobraževanja (Ritchey, 2008), ki poskuša povečati priložnosti za sodelovanje in aktivno vključevanje v družbo.

\section{ZAKLJUČEK}

Pritisk na civilno družbo, ki je vse bolj individualistično naravnana in nezaupljiva do okolja, postavlja $\mathrm{v}$ ospredje potrebo po novih načinih 
Funkcija skupnostnega izobraževanja je tako postati povezovalni člen različnih organizacij v skupnosti, krajanov in lokalne oblasti ter povezovalni člen krajanov samih, vendar bi bilo preoptimistično pričakovati, da bi skupnostno izobraževanje lahko preseglo dominantne verske okvire, ki določajo razmišljanje in delovanje posameznika. V okolju in razmerah, ki vladajo $\mathrm{v}$ tej podeželski skupnosti, pa ima skupnostno izobraževanje priložnost doseganja pozitivnih sprememb na področju zmanjševanja pasivnosti krajanov, saj bi se več kot polovica anketirancev (61,5 odstotka) vključila v obliko izobraževanja, ki v okviru skupnostnih aktivnosti gradi na medsebojnem povezovanju in podpori krajanov ter slednjim ponuja možnosti za razvoj njihovega znanja in spretnosti, s katerimi bi lahko prispevali tudi $\mathrm{k}$ razvoju svoje podeželske skupnosti.

povezovanja ljudi. Sistem izobraževanja odraslih potrebuje nove oblike neformalnega izobraževanja, ki bi povečale enakost možnosti za izobraževanje vseh državljanov in spodbudile aktivno vključevanje $\mathrm{v}$ družbo ter s tem znižale stopnjo socialne izključenosti. Ena od takih oblik je skupnostno izobraževanje, ki pa bi moralo ponuditi takšne dejavnosti in projekte, v katerih bi se vzpostavljali dobri medosebni odnosi v skupnosti, spodbujalo partnerstvo in sodelovanje med posamezniki in skupinami ter krajani in lokalno oblastjo. Skupnostno partnerstvo lahko odpre nove poti in nove programe, ki služijo potrebam skupnosti. Obenem pa bi se morali krajani začeti zavedati možnosti lastnega prispevka k izboljševanju razmer za življenje v skupnosti, pri čemer bi morali biti izpolnjeni tudi pogoji za sodelovanje v procesu odločanja. Poleg volitev in svétov lahko krajani o zadevah lokalne samouprave odločajo tudi neposredno (zbori, referendumi ali odločanje prek ljudske iniciative). $Z$ neposrednimi oblikami naj bi ugotavljali stališče krajanov do problemov, ki jih ti zaznavajo v svoji lokalni skupnosti. Ugotavljamo, da je lokalna samouprava pri razvoju oblik neposrednega odločanja $v$ velikem zaostanku za evropskimi koncepti in pobudami, ki kličejo po aktivaciji in sodelovanju državljanov v razvoju skupnosti. Tudi v Izhodiščih in predlogih za nadaljnji razvoj lokalne samouprave v RS (2001) je zapisano, da bo služba za lokalno samoupravo predvidela nove načine, s katerimi bi zagotovili povečanje interesa za neposredno odločanje in sodelovanje pri nevladnih organizacijah ter možnosti vključitve civilnopravnih oblik v odlo- čanje na lokalni ravni. Možnost članov lokalne skupnosti, da neposredno odločajo o aktualnih zadevah, povečuje njihov interes za sodelovanje pri razvoju, identificiranju skupnostnih problemov in njihovem reševanju. Vendar pa za to, da bodo lahko sodelovali pri razvoju družbe in doseganju trajnostnih ciljev, potrebujejo tudi znanje in spretnosti. Krajani bi v procesu sodelovanja pri odločanju odkrivali svoje nezapolnjene vrzeli v znanju. S tem bi se njihova motivacija za vključevanje v izobraževanje lahko povečala, obstaja pa nevarnost, da bi od sodelovanja pri razvoju skupnosti tudi odstopili.

\section{LITERATURA}

Banathy, B. H. (2000). Guided evolution of society: a systems view. New York: Kluwer Academic / Plenum Publishers, cop 2000.

Brenk, E. (2007). Pregled ponudbe izobraževanja in učenja odraslih v Sloveniji v šolskem letu 2007/2008. Poročilo in analiza. Ljubljana: Andragoški center Slovenije.

Community education (2000). AONTAS policy series 1: Community education. Dublin: National Association of Adult Education, AONTAS.

Findeisen, D. (1996). »O skupnostnem izobraževanju in razvoju kraja«. Andragoška spoznanja, 3: 27-32.

Grant, B., Horrocks, N. (2004). First steps to commuity development learning. England: National institite of adult education.

Izzivi podeželja (UŽU-IP) (2005). http://programoteka.acs.si/PDF/UZU_IP_program.pdf, pridobljeno 9.1.2009)

Izhodišča in predlogi za nadaljnji razvoj lokalne samouprave v Republiki Sloveniji (2005). (www.svlr.gov.si/ fileadmin/svlsrp.gov.si/pageuploads/lok-sam05/sklepivrs/izhod187.htm) 
Jelenc, S. (1996). ABC izobraževanja odraslih. Ljubljana: Andragoški center Slovenije.

Jelenc, Z. (1990). Izobraževanje odraslih in Evropa '92: Zbornik prispevkov s posveta. Ljubljana: Andragoško društvo Slovenije.

Jelenc, Z. (2007a). Strategija in koncepcija izobraževanja odraslih v Sloveniji. (http://oa1-seminar.naspletu.com/zjelencporocilo.html)

Jelenc, Z. (2007b). Strategija vseživljenjskosti učenja v Sloveniji. (http://oa1-seminar.naspletu.com/strategija07.pdf)

Krajnc, A. (1996). »Izobraževanje odraslih in lokalni razvoj«. Andragoška spoznanja, št. 3: 23-26.

Kump, S., Jelenc Krašovec, S. (2005). »Izobraževanje - možni dejavnik krepitve moči in vpliva starejših odraslih«. Družboslovne razprave: letn. XX1, št. 49/50, str. 243-262. Univerza v Ljubljani: Fakulteta za družbene vede, Slovensko sociološko društvo.

Ličen, N. (1996). »Društva nekoč in danes z vidika skupnostnega izobraževanja«. Andragoška spoznanja, 3: 45-52.

Ličen, N. (2001). »Socialni kapital in izobraževalne potrebe v obdobju spreminjanja dela in trga «. Andragoška spoznanja, 4: 14-16.

Ličen, N. (2006). Uvod v izobraževanje odraslih: izobraževanje odraslih med moderno in postmoderno. Ljubljana: Filozofska fakulteta, Oddelek za pedagogiko in andragogiko.

Mandič. S., Hlebec, V. (2005). »Socialno omrežje kot okvir upravljanja s kakovostjo življenja in spremembe $\mathrm{v}$ Sloveniji med letoma 1987 in 2002 «. Družboslovne razprave: letn. XX1, št. 49/50: 263; Univerza v Ljubljani: Fakulteta za družbene vede, Slovensko sociološko društvo.
Mlinar, Z. (1973). Sociologija lokalnih skupnosti. Ljubljana: Univerza v Ljubljani, Fakulteta za sociologijo, politične vede in novinarstvo.

Močnik, V. (2009). Skupnostno izobraževanje kot adut trajnostnega razvoja podeželja. Diplomska naloga. Univerza v Ljubljani, Filozofska fakulteta.

Nacionalna strategija za razvoj pismenosti (2006). (http://arhiv.acs.si/publikacije/NSRP.pdf )

Poster, C., Krüger, A. (1990). Community education in the western world. London, New York: Routledge.

Reed, S. C., Marienau, C. (ur.). (Smith, M. C., Holland, B.\&Robinson, G., Ritcher-Hauk, R.\&Arias, J., Largent, L.\&Horinek, J.B., Mündel, K.\&Schugurensky, D., Reed, S.C.\&Marienau, C., Fiddler, M\&Marienau, C., Chickring, A. W.). (2008). Linking adults with community: Promoting civic engagement through community based learning. San Francisco: Wiley peridiocals, INC.

Resolucija o nacionalnem programu izobraževanja odraslih v Republiki Sloveniji do leta 2010 (ReNPIO) (2004). (http://www.uradni-list.si/1/objava. jsp?urlid=200470\&stevilka=3149)

Ritchey A., J. (ur.) (2008). Adult education in the rural context: People, Place and Change. San Francisco. (Zacharakis, J., Zigler F., M\&Davis C., D., McLughlin, J., Rodriguez, M., Madden, C., Mott W., V., Page, G. A., Hill, M., Reardon F., R., Brooks K., A., Bracken J., S.).

Smith, M. K. (2008). The encyclopedia of informal education. (http://www.infed.org).

»Zakon o lokalni samoupravi« (ZLS) Ur. 1. RS, št. 72/1993. (http://www2.gov.si/zak/zak_vel.nsf/ zakposop/1993-01-2629?OpenDocument) 